УдК 342.95:001.89

DOI https://doi.org/10.51989/NUL.2021.4.17

\title{
ПРАВОВЕ ЗАБЕЗПЕЧЕННЯ ЕКСПЕРТНОЇ ДІЯЛЬНОСТІ У СФЕРI ТЕХНІЧНОГО РЕГУЛЮВАННЯ
}

\author{
Смерницький Дем'ян Вікторович, \\ доктор юридичних наук, старший дослідник, \\ заступник директора \\ Державного науково-дослідного інституту Міністерства внутрішніх справ України
}

У статті розглянуто правове забезпечення експертної діяльності у сфері технічного регулювання. До науково-технічної експертизи у сфері технічного регулювання, яке визначено як правове регулювання відносин у сфері визначення та виконання обов'язкових вимог до характеристик продукції або пов'язаних з ними процесів та методів виробництва, а також перевірки їх додержання шляхом оцінки відповідності та/або державного ринкового нагляду і контролю нехарчової продукції чи інших видів державного нагляду (контролю), ми віднесли добровільну та обов'язкову оцінку відповідності, добровільну сертифікацію а також випробування для визначення однієї чи кількох характеристик об'єкта оцінки відповідності згідно з процедурою. Також до науково-технічної експертизи у сфері технічного регулювання варто віднести експертизу нормативно-правових актів (технічних регламентів) та нормативних документів (стандартів, кодексів усталеної практики й технічних умов). Суб'єктом, який проводить експертизу (оцінку відповідності), виступає орган з оцінки відповідності, а саме орган (підприємство, установа, організація чи їх структурний підрозділ), що здійснює діяльність з оцінки відповідності, включаючи калібрування, випробування, сертифікацію та інспектування, а також у проведенні експертиз бере участь випробувальна лабораторія. У сфері технічного регулювання до технічних регламентів застосовується правова експертиза, оскільки вони є нормативно-правовими актами. Стандарти є нормативними документами, а їх експертизу здійснює Національний орган стандартизації. Крім того, до нормативно-правових актів та нормативних документів у сфері технічного регулювання може бути застосована в різних випадках: антикорупційна, наукова, науково-технічна, патентна, правова, технічна, технологічна, економічна, екологічна та інші види експертиз.

Ключові слова: експертна діяльність, технічне регулювання, технічні регламенти, національні стандарти, науково-технічна експертиза, правова експертиза.

\section{Smernytskyi Demian. Legal provision of expert activity in the field of technical regulation}

The article considers the legal support of expert activities in the field of technical regulation. To scientific and technical expertise in the field of technical regulation, which is defined as the legal regulation of relations in the field of defining and fulfilling mandatory requirements for product characteristics or related processes and production methods, as well as verifying their compliance by conformity assessment and/or state market surveillance and control of non-food products or other types of state supervision (control), we have included voluntary and mandatory conformity assessment, voluntary certification and testing to determine one or more characteristics of the object of conformity assessment in accordance with the procedure. Also, the scientific and technical expertise in the field of technical regulation should include the examination of normative legal acts (technical regulations) and normative documents (standards, codes of practice and technical conditions). The entity conducting the examination (conformity assessment) is the conformity assessment body, namely the body (enterprise, institution, organization or their structural subdivision) that performs conformity assessment activities, including calibration, testing, certification and inspection, as well as in the testing laboratory takes part in carrying out examinations. In the field of technical regulation, legal expertise is applied to technical regulations because they are normative legal acts. Standards are normative documents and their examination is carried out by the National Standardization Body. In addition, to regulations and regulations in the field of technical regulation can be applied in various cases: anti-corruption, scientific, scientific and technical, patent, legal, technical, technological, economic, environmental and other types of expertise.

Key words: expert activity, technical regulation, technical regulations, national standards, scientific and technical expertise, legal expertise. 
Ураховуючи те, що загалом експертиза - це розгляд, дослідження певної справи, якогось питання з метою зробити правильний висновок або дати правильну оцінку відповідному явищу [1, с. 462], то під науковою і науково-технічною експертизою потрібно розуміти діяльність, метою якої $\epsilon$ дослідження, перевірка, аналіз та оцінювання науково-технічного рівня об'єктів експертизи і підготовка обґрунтованих висновків для прийняття рішень щодо таких об'єктів [2].

Оцінювання науково-технічного рівня об'єкта слід розглядати не лише в його співвідношенні з аналогічними об'єктами з метою визначення провідного, прогресивного об'єкта, а й у відношенні об'єкта до встановлених норм з безпеки, екологічності, можливості діяти сумісно з іншими об'єктами тощо [3, с. 346].

Правові, організаційні, фінансові основи експертної діяльності в науковотехнічній сфері, а також загальні основи і принципи регулювання суспільних відносин у галузі організації та проведення наукової та науково-технічної експертизи з метою забезпечення наукового обґрунтування структури і змісту пріоритетних напрямів розвитку науки і техніки, наукових, науково-технічних, соціально-економічних, екологічних програм і проєктів, визначення напрямів науково-технічної діяльності, аналізу та оцінки ефективності використання науково-технічного потенціалу визначає Закон України «Про наукову і науково-технічну експертизу» [4].

Відомо, що спектр експертиз, який визначений нормативно-правовими документами, значний та зумовлений суспільними відносинами в певній сфері. Експертизи за своїм призначенням та видом бувають науково-технічними, науковими, судовими, правовими, екологічними, патентними тощо [3, с. 347].

Відповідно до Закону України «Про наукову і науково-технічну експертизу» наукова і науково-технічна експертиза у сфері науково-технічних розробок та дослідноконструкторських робіт, фундаментальних і прикладних досліджень, зокрема на стадії їх практичного застосування (впровадження, використання, наслідки використання тощо), проводиться науководослідними організаціями та установами, закладами вищої освіти, іншими організаціями та окремими юридичними і фізичними особами, які акредитовані на цей вид діяльності [4].

Об'єктами наукової та науково-технічної експертизи відповідно до ст. 5 Закону [4] можуть бути діючі об'єкти техніки (зокрема, військової) та промисловості, споруди, природні об'єкти тощо, стосовно яких виникає потреба отримати науково обґрунтовані експертні висновки; проєкти, програми, пропозиції різного рівня, щодо яких необхідно провести науково обґрунтований аналіз і дати висновок про доцільність їх прийняття, впровадження, подальшого використання тощо.

Статтею 9 Закону [4] визначені державна і громадська форми експертизи, а державна експертиза $\epsilon$ обов'язковою. На нашу думку, доцільніше встановити обов'язкову та необов'язкову (добровільну) форми експертизи. До обов'язкової віднести науково-технічну експертизу, яка згідно з нормативно-правовими документами $\epsilon$ обов'язковою, це експертиза, наприклад, виробів на безпеку, науковотехнічних програм на економічну доцільність, на екологічність тощо. Обов'язкову науково-технічну експертизу можуть здійснювати як державні органи, так і недержавні установи у випадку надання їм відповідного дозволу (ліцензії, акредитації тощо). Необов'язкову (добровільну) науково-технічну експертизу наукові установи, підприємства можуть проходити добровільно з метою визначення ситуації або прийняття відповідного рішення щодо об'єкта, який проходить експертизу. Цю експертизу теж можуть проводити як державні, так і недержавні установи за наявності відповідних фахівців та дозволу на цей вид діяльності.

Слід зазначити, що сфера науково-технічної експертизи набагато ширша, ніж визначено в Законі [4]. До неї, на нашу думку, можна віднести, наприклад, оцінку відповідності продукції в науково-технічній галузі, яка $\epsilon$ як обов'язковою, так і не обов'язковою та спрямована на визначення відповідності створеної технічної продукції нормативно-правовим документам - технічним регламентам, і добровільну сертифікацію, яка визначає відповідність національним стандартам України, 
де встановлені відповідні норми та параметри щодо цієї продукції [5, с. 48].

Так згідно із Законом України «Про технічні регламенти та оцінку відповідності», оцінка відповідності це - процес доведення того, що задані вимоги, які стосуються продукції, процесу, послуги, системи, особи чи органу, були виконані. Об'єктом оцінки відповідності виступають конкретний матеріал, продукція, установка, процес, послуга, система, особа чи орган, до яких застосовується оцінка відповідності [6].

Суб'єктом, який проводить експертизу (оцінку відповідності), виступає орган з оцінки відповідності, а саме орган (підприємство, установа, організація чи їх структурний підрозділ), що здійснює діяльність з оцінки відповідності, включаючи калібрування, випробування, сертифікацію та інспектування.

Крім того, в експертизі бере участь ще один суб'єкт - випробувальна лабораторія. Випробувальна лабораторія (орган з оцінки відповідності) під час проведення зазначеного виду науково-технічної експертизи проводить випробування, тобто визначення однієї чи кількох характеристик об'єкта оцінки відповідності згідно з процедурою.

Також до певного виду науково-технічної експертизи ми віднесли сертифікацію - підтвердження відповідності третьою стороною, яке стосується продукції, процесів, послуг, систем або персоналу, яка теж проводиться органом з оцінки відповідності.

Згідно зі ст. 11 Закону України «Про технічні регламенти та оцінку відповідності», продукція, що вводиться в обіг, надається на ринку або вводиться в експлуатацію, а згідно з деякими технічними регламентами - також продукція, що виготовляється та/або вводиться в експлуатацію виробником для використання у власних цілях, повинна відповідати вимогам усіх чинних технічних регламентів, які застосовуються до такої продукції [6].

Відповідність продукції вимогам технічних регламентів може бути забезпечена шляхом застосування національних стандартів та/або інших технічних специфікацій, посилання на які містяться у відповідних технічних регламентах. у технічному регламенті зазначається, чи $\epsilon$ відповідність продукції таким національним стандартам та/або іншим технічним специфікаціям єдиним способом, чи одним зі способів задоволення вимог цього технічного регламенту. Посилання в технічних регламентах на зазначені національні стандарти можуть мати форму переліків національних стандартів для цілей застосування відповідних технічних регламентів.

Процедури оцінки відповідності (проведення науково-технічної експертизи), застосування яких передбачене технічними регламентами, відповідно до ст. 14 Закону [6] розробляються, приймаються і застосовуються на основі принципів, установлених Угодою Світової організації торгівлі про технічні бар'єри в торгівлі [7], що $є$ додатком до Марракеської угоди про заснування Світової організації торгівлі 1994 р. [8].

Як зазначено у ст. 24 Закону [6], здійснення добровільної оцінки відповідності не вимагається технічними регламентами, вона здійснюється на добровільних засадах, у будь-яких формах, включаючи випробування, декларування відповідності, сертифікацію та інспектування, та на відповідність будь-яким заявленим вимогам.

Оцінка відповідності вимогам технічних регламентів (обов'язкова) здійснюється у випадках і шляхом застосування процедур оцінки відповідності, які визначені в таких технічних регламентах (ст. 25 Закону) [6].

Отже, ми віднесли до науково-технічної експертизи у сфері технічного регулювання, яке визначено як правове регулювання відносин у сфері визначення та виконання обов'язкових вимог до характеристик продукції або пов'язаних з ними процесів та методів виробництва, а також перевірки їх додержання шляхом оцінки відповідності та/або державного ринкового нагляду і контролю нехарчової продукції чи інших видів державного нагляду (контролю) [6], добровільну та обов'язкову оцінку відповідності, добровільну сертифікацію а також випробування для визначення однієї чи кількох характеристик об'єкта оцінки відповідності згідно з процедурою. 
Також до науково-технічної експертизи у сфері технічного регулювання варто віднести експертизу нормативно-правових актів (технічних регламентів) і нормативних документів (стандартів, кодексів усталеної практики та технічних умов).

Так, технічний регламент визначено як нормативно-правовий акт, в якому визначено характеристики продукції або пов'язані з ними процеси та методи виробництва, включаючи відповідні адміністративні положення, додержання яких $\epsilon$ обов'язковим [6]. Наукова експертиза технічних регламентів проводиться тим суб'єктом, який надає йому чинності.

У відповідності до Закону України «Про стандартизацію» [9] стандарт це - нормативний документ, заснований на консенсусі, прийнятий визнаним органом, що встановлює для загального і неодноразового використання правила, настанови або характеристики щодо діяльності чи ії результатів, та спрямований на досягнення оптимального ступеня впорядкованості в певній сфері.

Кодекс усталеної практики визначено як нормативний документ, що містить рекомендації щодо практик чи процедур проектування, виготовлення, монтажу, технічного обслуговування або експлуатації обладнання, конструкцій чи виробів.

А технічні умови це - нормативний документ, що встановлює технічні вимоги, яким повинна відповідати продукція, процес або послуга, та визначає процедури, за допомогою яких може бути встановлено, чи дотримані такі вимоги [9].

Як зазначає I. Онищук, у процесі нормотворчої діяльності, що $€$ найважливішим видом юридичної діяльності, за допомогою якого створюються правові регулятори в суспільстві, проводяться різні види експертиз нормативно-правових актів та їх проектів з метою виявлення і усунення недоліків. Проведення цих експертиз - один із невід'ємних елементів нормотворчого процесу, спрямований на забезпечення якості правового акта. До таких експертиз можна віднести: правову, антикорупційну, лінгвістичну, технічну, соціальну, фінансово-економічну, гендерну, наукову тощо.

Під правовою експертизою автор розуміє засноване на застосуванні спеціальних знань дослідження, що проводиться експертом з метою використання його результатів у юридичній діяльності [10, с. 123].

У відповідності до Методичних рекомендацій щодо проведення правової експертизи проектів нормативно-правових актів (схваленої постановою колегії Міністерства юстиції України від 21 листопада 2000 року № 41) правова експертиза може бути проведена щодо проєкту: закону України; указу Президента України; постанови Кабінету Міністрів України; постанови Національного банку України; наказу міністерства, іншого центрального органу виконавчої влади.

Завданнями правової експертизи проєкту нормативно-правового акта $€$ :

- об'єктивне і повне дослідження поданого на розгляд експертів проєкту відповідно до предмета експертизи, виходячи із загальносуспільних та загальнодержавних інтересів, засад побудови правової системи;

- розроблення в разі необхідності пропозицій щодо внесення до проєкту або інших пов'язаних з ним нормативно-правових актів необхідних змін і доповнень;

- підготовка обґрунтованого експертного висновку з усебічною оцінкою проєкту нормативно-правового акта [11].

Отже, у сфері технічного регулювання до технічних регламентів застосовується правова експертиза, оскільки вони $\epsilon$ нормативно-правовими актами.

Щодо національних стандартів та кодексів усталеної практики вони $€$ нормативними документами, а їх експертизу здійснює Національний орган стандартизації, який організовує та координує діяльність із проведення перевірки національних стандартів та кодексів усталеної практики на відповідність законодавству, потребам виробників та споживачів, рівню розвитку науки і техніки, інтересам держави, вимогам міжнародних, регіональних стандартів та кодексів усталеної практики [9].

Науково-технічну експертизу щодо інших стандартів та технічних умов проводять відповідні компетентні установи, яким згідно з чинним законодавством надано право на проведення зазначеної експертизи, а також суб'єкти, які надають чинності наведеним нормативним документам. 
Крім того, до нормативно-правових актів та нормативних документів у сфері технічного регулювання експертиза може бути застосована в різних випадках, тому існує антикорупційна, наукова, науковотехнічна, патентна, правова, технічна, технологічна, економічна, екологічна та інші види експертиз.

Підбиваючи підсумки, ще раз наведемо визначений нами узагальнений пере- лік видів науково-технічної експертизи у сфері технічного регулювання, а саме: добровільна та обов'язкова оцінка відповідності, добровільна сертифікація, випробування для визначення однієї чи кількох характеристик об'єкта оцінки відповідності згідно з процедурою, експертиза технічних регламентів, стандартів, кодексів усталеної практики та технічних умов.

\section{ЛITEPATУPA:}

1. Словник української мови : в 11 т. / АН УРСР. Інститут мовознавства ; за ред. І.К. Білодіда. Київ : Наукова думка, 1970-1980. Т. 2.

2. Адміністративне право України : підруч. / за заг. ред. Т.О. Коломоєць. Київ : «Істина», 2008.

3. Смерницький Д.В. Адміністративно-правове регулювання науково-технічної діяльності в Україні : дис. ... док. юрид. наук. : 12.00.07. Київ, 2020. 636 с.

4. Про наукову і науково-технічну експертизу : Закон України від 10 лютого 1995 року № 51/95-ВР. Відомості Верховної Ради України. 1995. № 9. Ст. 56.

5. Смерницький Д.В. Науково-технічна експертиза у сфері науково-технічної діяльності: правове забезпечення. Наука і правоохорона. 2016. № 4 (34). С. 45-54.

6. Про технічні регламенти та оцінку відповідності : Закон України від 15 січня 2015 року № 124-VIII. Відомості Верховної Ради (ВВР). 2015. № 14. Ст. 96.

7. Про технічні бар'єри в торгівлі Світової організації торгівлі: Угода ТБТ СОТ від 15 квітня 1994 року. Документ 981_008.

8. Про заснування Світової організації торгівлі : Марракеська угода від 15 квітня 1994 року.

9. Про стандартизацію : Закон України від 5 червня 2014 року № 1315-VII. Відомості Верховної Ради (ВВР). 2014. № 31. Ст. 1058.

10. Онищук I. Моніторингова експертиза проектів нормативно-правових актів. Науковий часопис Національної академії прокуратури України. 2014. № 4. С. 122-133.

11. Методичні рекомендації щодо проведення правової експертизи проектів нормативноправових актів. Схвалено постановою колегії Міністерства юстиції України від 21 листопада 2000 року № 41. 